\title{
IMPLEMENTASI PERATURAN BADAN PENGATUR HILIR MINYAK DAN GAS BUMI NOMOR 06 TAHUN 20 I5 TENTANG PENYALURAN JENIS BAHAN BAKAR MINYAK TERTENTU DAN JENIS BAHAN BAKAR KHUSUS PENUGASAN PADA DAERAH TANPA PENYALUR DI KABUPATEN KATINGAN
}

\author{
Implementation of Regulation of the Downstream Oil and Gas Regulatory Agency \\ Number 06 of 2015 concerning Distribution of Specific Types of Fuel Oil and Types of \\ Fuels Specially Assignment to Areas without Distributors in Katingan Regency
}

\section{Laksminarti*}

Nova Riyanti

Universitas Muhammadiyah Palangkaraya, Palangka Raya,

Central Kalimantan, Indonesia email: laksminarti@gmail.com

Kata Kunci:

Bahan Bakar Minyak

Implementasi

Sub-penyalur

Keywords:

Fuel Oil

Implementation

Sub-distributor

Accepted

June 2018

Published

October 2018

\begin{abstract}
Abstrak
Penelitian ini bertujuan untuk mengetahui Implementasi dari Peraturan Badan Pengatur Hilir Minyak dan Gas Bumi Nomor 06 Tahun 2015 tentang Penyaluran Jenis Bahan Bakar Minyak Tertentu dan Jenis Bahan Bakar Khusus Penugasan pada Daerah Tanpa Penyalur di Kabupaten Katingan. Tipe penelitian yang digunakan adalah metode penelitian kualitatif dengan teknik analisis deskriptif. Teknik pengumpulan data yang digunakan adalah observasi, wawancara dan dokumentasi. Informan yang diambil dalam penelitian ini dilakukan dengan teknik snowball sampling. Berdasarkan Hasil Penelitian Berdasarkan Hasil Penelitian mengenai Implementasi Peraturan Badan Pengatur Hilir Minyak dan Gas Bumi Nomor 06 Tahun 2015 dapat disimpulkan bahwa peraturan tersebut belum dapat terlaksana. Hal tersebut ditandai dengan tidak adannya pendirian sub-penyalur maupun penunjukan sub-penyalur. Saran yang bisa peneliti berikan pada pihak pemerintah daerah Kabupaten Katingan, hendaknya mempertimbangkan kebutuhan daerah dengan keterbatasan penyalur sehingga peneliti merasa perlunya pendirian sub penyalur yang dapat memperdayakan kelompok masyarakat melalui koperasi maupun Badan Usaha Milik Desa.
\end{abstract}

\begin{abstract}
This study aims to determine the implementation of the Regulation of the Downstream Oil and Gas Regulatory Agency Number 06 of 2015 concerning Distribution of Specific Types of Oil Fuels and Types of Fuels Specifically for Assignments to Areas without Distributors in Katingan District. The type of research used is qualitative research methods with descriptive analysis techniques. Data collection techniques used were observation, interviews and documentation. The informants taken in this study were carried out using the snowball sampling technique. Based on the results of the research based on the results of research on the implementation of the Regulation of the Downstream Oil and Gas Regulatory Agency Number 06 of 2015 it can be concluded that the regulation cannot be implemented. This is indicated by the absence of the establishment of sub-distributors and the appointment of sub-distributors. Suggestions that researchers can give to the local government of Katingan Regency, should consider the needs of regions with limited distribution so that researchers feel the need to establish sub-distributors that can empower community groups through cooperatives and Village-Owned Enterprises.
\end{abstract}

\section{PENDAHULUAN}

Badan Pengatur Hilir Minyak dan Gas Bumi (BPH Migas) adalah suatu badan yang dibentuk untuk melakukan pengaturan pengawasan terhadap penyediaan dan pendistribusian Bahan Bakar Minyak (BBM) dan Gas Bumi setra Pengangkutan Gas Bumi melalui pipa pada Kegiatan Usaha Hilir. Fungsi BPH Migas adalah melakukan pengawasan terhadap pelaksanaan penyediaan dan pendistribusian BBM dan Pengangkutan Gas Bumi melalui pipa, dalam suatu pengaturan agar ketersediaan dan distribusi BBM yang ditetapkan Pemerintah dapat terjamin di seluruh wilayah Negara Kesatuan Republik Indonesia meningkatkan pemanfaatan BBM dan Gas Bumi di dalam negeri. 
Bahan Bakar Minyak merupakan kebutuhan pokok bagi masyarakat desa maupun kota, baik sebagai kebutuhan rumah tangga maupun kebutuhan produksi dan distribusi pengusaha, terutama dalam menunjang operasional industri dan transportasi. Dari pengamatan yang peneliti lakukan, jumlah penyalur bahan bakar minyak tidak merata di Kabupaten Katingan. Hal tersebut karena masih ada daerah yang belum memiliki penyalur resmi bahan bakar minyak yang berupa Stasiun Pengisian Bahan Bakar Umum (SPBU) dan Agen Premium \& Minyak Solar (APMS) di Kabupaten Katingan. Namun hanya ada 2 SPBU dan 3 APMS yang ada di Kabupaten Katingan. Letak penyalur tersebut juga hanya ada di 3 kecamatan saja, yaitu sebanyak 3 penyalur di Kecamatan Katingan Hilir, I penyalur di Kecamatan Katingan Tengah dan I penyalur di Kecamatan Pulau Malan yang letaknya berdekatan sedangkan di daerah lainnya tidak ada penyalur resmi.

Selain keterbatasan penyalur yang ada di Kabupaten Katingan, pengalaman empirik yang dirasakan oleh peneliti juga kerap kali mengalami keterlambatan dan kehabisan bahan bakar minyak yang ada penyalur sehingga tidak bisa membeli bahan bakar minyak di penyalur resmi yaitu SPBU atau APMS yang ada. Keterbatasan penyalur di Kabupaten Katingan membuat pola distribusi bahan bakar minyak tersebut di kuasai oleh pihak pengecer/kios bahan bakar minyak.

\section{METODOLOGI}

Metode pelaksanaan yang dilakukan pada penelitian ini menggunakan metode kualitatif. Alasan peneliti menggunakan kualitatif adalah dikarenakan penelitian ini ingin mengetahui keseluruhan tentang Implementasi Peraturan Badan Pengatur Hilir Minyak dan Gas Bumi Nomor 06 Tahun 2015 tentang Penyaluran Jenis Bahan Bakar Minyak Tertentu dan Jenis Bahan Bakar Khusus Penugasan pada Daerah Tanpa Penyalur di Kabupaten Katingan.

\section{HASIL DAN PEMBAHASAN}

Berdasarkan hasil penelitian sebenernnya Peraturan BPH Migas Nomor 06 Tahun 2015 belum dipahami oleh keseluruhan birokrasi yang menjadi implementor, memang dalam pelaksanaan ini tidak hanya fokus pada I instansi saja sehingga ada beberapa instansi pemerintahan yang dilakukan penelitian. Pada awalnnya, Perwakilan pusat dari Komite BPH Migas telah melakukan sosialisasi secara langsung dan bekerjasama dengan Pemerintah Provinsi Kalimantan Tengah dalam penyebarluasannya. Hal yang menjadi tidak terlaksanannya peraturan tersebut di pemerintah daerah/kabupaten adalah rancunya kewenangan instansi satu sama lain di lingkup pemerintah kabupaten. Hal ini terjadi karena Dinas Pertambangan dan Energi yang ada di Kabupaten Katingan dibubarkan dan kewenangan migas pemerintah kabupaten/kota ditarik ke Pemerintah Pusat.

Pemangkasan Dinas Pertambangan dan Energi Kabupaten itu menghilangkan tugas dan fungsinnya. Dan secara langsung diambil alih Distamben Provinsi sesuai dengan Undang-Undang Nomor 23 tahun 2014 tentang Mineral dan Pertambangan (minerba). Demikian pula dengan sanksi-sanksi yang diatur dalam Peraturan BPH Migas Nomor 06 Tahun 2015 yang merujuk kepada Undang-Undang Nomor 22 Tahun 200I tentang Minyak dan Gas Bumi belum dapat terlaksana dengan baik. Pada dasarnya aturan ini untuk menertibkan banyaknya pengecer illegal baik Pengecer/Kios BBM maupun pertamini yang selama ini menguasai pola distribusi BBM itu sendiri. Namun dengan tidak adannya peminat atau pihak-pihak yang menjadi sub penyalur dalam pelaksanaan aturan maka sanksi-sanksi pun tidak dapat diberlakukan dengan baik pula.

Kemudian, peneliti mendalami dengan melihat ada atau tidaknnya keberatan-keberatan yang muncul dari aturan ini, hambatan-hambatan yang terjadi dan keluhankeluhan dari berbagai pihak. Pertama, Dalam hal Peraturan BPH Migas Nomor 06 Tahun 2015, pada 
dasarnnya pemerintah ingin menjamin ketersediaan dan kelancaran pendistribusi- an BBM di seluruh wilayah NKRI sehingga keadilan BBM dapat dinikmati sampai kepelosok negeri. Tentunnya hal ini tidak perlu ada yang merasa keberatan karena dalam aturan ini hanya mengatur pendirian sub penyalur dalam melancarkan pendistribusian BBM. Tetapi, memang dalam pendirian sub penyalur ini nantinya akan ada penertiban karena selama ini pendistribusian BBM dikuasai oleh pihak yang tergolong ileggal dari pelangsir minyak botolan maupun pertamini. Sehingga yang merasa keberatan dalam aturan ini adalah pihak-pihak yang bergantung pada penjualan BBM baik itu pelangsir, penjual BBM eceran dan Pertamini.

Kedua, dalam mengimplementasi kan Peraturan BPH Migas Nomor 06 Tahun 2015 yang menjadi salah satu penghambat adalah sosialisasi dan koordinasi yang juga sudah dibahas di indikator pertama. Sosialisasi dan koordinasi ini sudah diupayakan oleh pihak pusat melalui komite BPH Migas yang melakukan sosialisasi yang bekerjasama dengan Pemerintah Provinsi Kalimantan Tengah melalui Dinas Energi dan Sumber Daya Mineral Provinsi Kalimantan Tengah. Untuk mengawasi berkaitan dengan Migas, ada tim pengawas yang terdiri dari pegawai pusat dan pegawai yang bekerja di Dinas ESDM Provinsi Kalimantan Tengah. Koordinasi yang telah dilakukan oleh tim pengawas kepada pemerintah daerah itu sebenarnnya telah dilakukan tetapi belum berbuah manis. Pemerintah daerah yang memiliki kewenangan dalam penunjukan sub penyalur tidak memiliki peminatnya. Ketiadaan sub penyalur di Kabupaten Katingan menunjukan bahwa kurang sosialisasi dan koordinasi yang dilakukan tidak berjalan dengan baik.

Ketiga, Keluhan-keluhan yang muncul tidak datang dari masyarakat karena masyarakat secara umum belum mengetahui dan memahami aturan ini. Sehingga keluhan terhadap Peraturan BPH Migas Nomor 06 Tahun 2015 yang terjadi sehingga tidak terimplementasinnya aturan ini adalah dari peminat atau pihak yang ingin menjadi penyalur. Keluhan ini lebih pada pihak pengusaha yang ingin menjadi sub penyalur, dimana mereka memikirkan keuntungan dan kerugian bila berinvestasi sebagai sub penyalur. Mereka mengeluhkan dengan kebijakan sarana dan penyimpanan dengan kapasitas yang dianggap terlalu sedikit yaitu 3.000 liter saja.

Kemudian keluhan lain juga karena dalam aturan ini hanya menyalurkan solar dan premium sehingga mereka sangat ragu dalam menyalurkan 2 jenis BBM itu saja. Belum lagi kekhawatiran pihak pengusaha yang melihat alokasi kedua jenis BBM tersebut mengalami pengurangan secara nasional dan pendistribusian setiap daerah berbeda- beda. Sehingga lebih lanjut, peneliti melihat dari sisi kinerja. Menurut Pasolong (20/3) konsep kinerja pada dasarnya dapat dilihat dari dua segi, yaitu kinerja pegawai (perindividu) dan kinerja organisasi.

Sehubungan dengan belum terimplementasi Peraturan BPH Migas Nomor 06 Tahun 2015 dengan baik di Kalimantan Tengah, peneliti menilai kinerja yang dimaksud adalah kinerja organisasi yang memiliki kewenangan dalam melaksankan aturan ini yaitu Dinas Energi dan Sumber Daya Mineral Provinsi Kalimantan Tengah. Sebenarnnya dinas tersebut telah berupaya melaksanakan aturan ini dengan adannya tim pengawas migas yang dibentuk dari pegawai lokal maupun pegawai pusat yang menjadi perwakilan untuk mengawasi ketersediaan dan distribusi migas yang ada di Kalimantan Tengah.

Dengan tidak adannya sub penyalur yang dibentuk maka sudah dikatakan bawa peraturan BPH Migas Nomor 06 Tahun 2015 belum dapat terimplementasi dengan baik. Dari data yang terkumpul baik wawancara, observasi dan dokumentasi yang dilakukan peneliti, ditemukan bahwa selama ini dalam melaksanakan peraturan yang dilakukan tim pengawas migas tersebut terhenti pada pendataan yang dilakukan kepada setiap daerah/kabupaten yang tidak ada respon daerah 
terhadap kebutuhan dan peminat dari sub penyalur yang bersedia berinvestasi. Kemudian, sejauh ini belum ada langkah khusus untuk mengimplementasi kan aturan tersebut.

\section{KESIMPULAN}

Berdasarkan hasil penelitian yang telah dilakukan dalam penelitian ini, maka dapat disimpulkan beberapa hal, diantaranya sosialisasi yang dilakukan belum optimal karena masih ada para implementor yang belum mengetahui dan belum memahami aturan yang ada. Kemudian sosialisasi yang dilakukan juga belum menyentuh ke semua lapisan masyarakat. Selain itu, tidak ada pihak yang berminat menjadi sub penyalur karena sisi regulasi yang hanya mencakup jenis bahan bakar minyak premium dan solar, kapasitas penyimpanan yang dianggap sedikit, kuota nasional yang tidak menentu sehingga menjadi pertimbangan keuntungan dan kerugian para pengusaha atau pihak yang ingin menjadi sub penyalur. Kinerja yang selama ini dilakukan juga dirasa masih kurang maksimal.

\section{REFERENSI}

Afifudin \& Saebani, B.A. 20I2. Metode Penelitian Kualitatif. Bandung: Pustaka Setia.

Anggara, S. 2012. Ilmu Administrasi Negara. Bandung: Pustaka Setia.

Agustino, L. 2014. Dasar-Dasar Kebijakan Publik. Bandung: Alfabeta.

Moelong, L.J. 2002. Manajemen Penelitian Kualitatif. Bandung: Remaja Rosdakarya.

Pasolong, H. 20I3. Teori Administrasi Publik. Bandung: Alfabeta.

Peraturan Badan Pengatur Hilir Minyak Dan Gas Bumi Nomor 06 Tahun 2015 Tentang Penyaluran Jenis Bahan Bakar Minyak Tertentu Dan Jenis Bahan Khusus Penugasan Pada Daerah Yang Belum Terdapat Penyalur.

Subarsono, AG. 20I5. Analisis Kebijakan Publik. Yogyakarta: Pustaka Pelajar.
Sugiyono. 2008. Metode Penelitian Administrasi dilengkapi dengan Metode R\&D. Bandung: Alfabeta.

Sugiyono. 20I4. Memahami Penelitian Kualitatif. Bandung: Alfabeta. 